\title{
EKSPERIMENTASI MODEL PEMBELAJARAN \\ KOOPERATIF TIPE GROUP INVESTIGATION (GI) DAN TIPE THINK PAIR SHARE (TPS) DENGAN PENDEKATAN SAINTIFIK PADA MATERI POKOK HIMPUNAN DITINJAU DARI ADVERSITY QUOTIENT (AQ)
}

\author{
Nur Ikawati ${ }^{1}$, Mardiyana ${ }^{2}$, Dewi Retno Sari Saputro ${ }^{3}$ \\ ${ }^{1,2,3}$ Prodi Magister Pendidikan Matematika, FKIP Universitas Sebelas Maret Surakarta
}

\begin{abstract}
The aim of the research was to know the effect of learning models on mathematics learning achievement viewed from the student Adversity Quotient (AQ). The learning models compared were the cooperative learning model of the Group Investigation with scientific approach (GI-S), the cooperative learning model of the Think Pair Share with scientific approach (TPS-S), and model of classical learning with scientific approach (K-S). The type of the research was a quasi experimental research with the factorial design of $3 \times 3$. The population were all students of Junior High School in Bantul regency on academic year 2014/2015. The samples of the research were taken by using the stratified cluster random sampling. The instruments used were mathematics achievement test and questionnaires of AQ. The hypotheses of the research were analyzed by using the two-way analysis of variance with unbalanced cells at the significance level of $\alpha=0,05$. The results of the research are as follows. 1) GI-S gives better mathematics achievements than TPS-S, and both gives better mathematics achievements than K-S. 2) Students with AQ type of climber have better mathematics achievements than students with AQ type of camper and type of quitter, while students with AQ type of camper have better mathematics achievements than students with AQ type of quitter. 3) For GI-S and TPS-S, students with AQ type of climber and type of camper have the same mathematics achievements, and students with AQ type of climber and type of camper gives better mathematics achievements than students with AQ type of quitter. For K-S, students with AQ type of climber have better mathematics achievements than students with AQ type of camper and type of quitter, and both have the same mathematics achievements. 4) For students with AQ type of climber and type of quitter, GI-S, TPS-S, and K-S gives the same mathematics achievement. For students with AQ type of camper, GI-S and TPS-S gives the same mathematics achievements, and both gives better mathematics achievements than K-S.
\end{abstract}

Keywords: GI, TPS, Classical, Scientific Approach, AQ

\section{PENDAHULUAN}

Matematika sebagai salah satu ilmu dasar mempunyai peranan penting dalam perkembangan ilmu dan teknologi. Sejalan dengan hal tersebut Ignacio, et al. (2006: 16) menyatakan bahwa

Learning mathematics has become a necessity for an individual's full development in today's complex society. Technological advances and the growing importance of the means of communication make it necessary for people to adapt to the new situations that are arising out of social change.

Lebih lanjut Furner dan Kumar (2007: 187) menyatakan bahwa "the integration of math and science encompasses a number of considerations, for example, teaching math entirely as a part of science, or teaching science entirely as a part of math". 
Belajar matematika sebagai suatu wadah yang memfasilitasi kemampuan bernalar, berkomunikasi, dan peningkatan kepercayaan diri siswa dalam kehidupan sehari-hari. Menurut Sudarman (2012: 60) rendahnya nilai matematika karena masih banyak siswa memilih sikap negatif terhadap matematika. Hal tersebut disebabkan oleh pengalaman siswa sebelumnya bahwa matematika adalah pelajaran yang sulit. Pada akhirnya prestasi belajar matematika tidak sesuai dengan yang diharapkan.

Hasil Ujian Nasional matematika tingkat SMP Negeri di Kabupaten Bantul tahun pelajaran 2013/2014, siswa yang tidak lulus 1.194 siswa dari 7.351 siswa atau $16,24 \%$ siswa tidak lulus. Berdasarkan analisis daya serap siswa tiap materi matematika menunjukkan hasil yang belum maksimal, khususnya pada materi himpunan. Pada materi himpunan daya serap untuk Kabupaten Bantul masih terbilang rendah dibandingkan dengan materi yang lain. Daya serap materi himpunan untuk Kabupaten Bantul adalah $53,31 \%$ dibawah Nasional yaitu 59,39\% (BSNP, 2014).

Berdasarkan hal tersebut, diperlukan usaha untuk meningkatkan prestasi belajar siswa. Salah satu usaha pemerintah untuk meningkatkan kualitas pendidikan di Indonesia dengan memperbaharui kurikulum. Kurikulum yang diterapkan sebelumnya adalah Kurikulum Tingkat Satuan Pendidikan (KTSP) yang diperbaharui menjadi Kurikulum 2013 dengan menggunakan pendekatan saintifik. Dalam proses pembelajaran diperlukan suatu model pembelajaran yang diharapkan dapat meningkatkan kemampuan siswa baik kemampuan kognitif, afektif maupun psikomotorik. Diantara model pembelajaran tersebut adalah model pembelajaran yang membiasakan siswa aktif dikelas sehingga akan mengembangkan sifat kreatif dan mandiri.

Pembelajaran klasikal adalah model pembelajaran yang biasa digunakan oleh guru dalam pembelajaran. Menurut Dimyati dan Mudjiono (2006: 170) para siswa diasumsikan mempunyai minat dan kecepatan belajar yang relatif sama. Dengan kondisi seperti ini, kondisi belajar siswa secara klasikal baik menyangkut kecepatan belajar, kesulitan belajar, dan minat belajar sukar untuk diperhatikan oleh guru. Sebagai bentuk implementasi dari kurikulum 2013 pengelolaan pembelajaran menggunakan pendekatan saintifik (K-S).

Pembelajaran yang menuntut peran aktif siswa dapat dilakukan dengan menggunakan model pembelajaran kooperatif. Terkait dengan hal tersebut Zakaria, et al. (2010) menyatakan bahwa "cooperative learning is an effective approach, which mathematics teachers need to incorporate in their teaching". Lebih lanjut penelitian Pandya (2011: 27) menyimpulkan bahwa "the study found that the effect of the cooperative learning model on students academic achievement is maximum". Dua model pembelajaran kooperatif yang inovatif dalam pelaksanaan pembelajaran yang sejalan 
dengan pandangan konstruktivisme dan sesuai dengan kompetensi dasar yang diharapkan pada materi pokok himpunan adalah model pembelajaran kooperatif tipe Group Investigation (GI) dan tipe Think Pair Share (TPS).

GI menuntut siswa untuk memiliki kemampuan yang baik dalam berkomunikasi dan dalam kemampuan proses berkelompok (Slavin, 2005: 215). Investigasi kelompok dimulai dengan guru menyediakan situasi stimulus atau masalah. Penelitian Fitriana (2010) menunjukkan hasil bahwa prestasi belajar matematika siswa dengan model pembelajaran tipe GI lebih baik dari pada model pembelajaran tipe STAD.

Lie (2007: 57) menyatakan bahwa pendekatan struktural TPS memberikan kesempatan kepada siswa untuk bekerja sendiri serta bekerjasama dengan orang lain, siswa saling berdiskusi untuk mengungkapkan idenya. Handayani (2010) dalam penelitiannya menyatakan bahwa prestasi belajar menggunakan model struktural TPS lebih baik dari pada prestasi belajar matematika siswa dengan menggunakan pembelajaran langsung.

Faktor lain yang mempengaruhi keberhasilan suatu proses pembelajaran dimungkinkan sikap siswa atau kemampuan siswa merespon suatu kesulitan dalam menyelesaikan permasalahan dikenal dengan Adversity Quotient (AQ). AQ dapat menjadi indikator untuk melihat bagaimanakah seseorang dapat mengatasi masalahnya, apakah mereka tidak mau menerima tantangan sedikitpun, ataukah mereka mundur ditengah jalan, atau bahkan mereka dapat keluar sebagai pemenang. Phoolka (2012: 67) dalam penelitiannya menyatakan bahwa " $A Q$ is the predictor of succes of a person in face of adversity, how he behaves in a tough situation, how he controls the situation, is he able to find the corect origin of the problem, whether he takes his due ownership in that situation, does he try to limit the effects of adversity and how optimistic he is that the adversity will eventually end".

Siswa yang mempunyai sikap tidak mau menerima tantangan dalam menyelesaikan soal matematika disebut tipe quitter, siswa yang mudah menyerah disebut tipe camper, dan siswa yang mempunyai sikap berusaha pantang menyerah disebut tipe climber. Nureini (2011) dalam penelitiannya menunjukkan bahwa prestasi belajar matematika siswa kelompok climber lebih baik dibandingkan kelompok camper dan quitter, sedangkan siswa kelompok camper sama dengan kelompok quitter pada pembelajaran matematika materi SPLDV.

Dari pemaparan sebelumnya GI dan TPS dimungkinkan mendukung penerapan pendekatan saintifik dalam kurikulum 2013. Oleh karena itu, peneliti tertarik menerapkan pembelajaran kooperatif tipe GI dengan pendekatan saintifik (GI-S) dan tipe TPS dengan pendekatan saintifik (TPS-S). GI-S dan TPS-S mempunyai kesamaan yaitu tanggung 
jawab maupun keaktifan individu sangat diutamakan. AQ sebagai kecerdasan seseorang dalam menghadapi kesulitan yang membantu siswa meningkatkan potensi diri dalam berpikir dan mengumpulkan informasi untuk menyelesaikan masalah.

Berdasarkan paparan tersebut penelitian ini bertujuan untuk mengetahui: (1) manakah model pembelajaran yang memberikan prestasi belajar siswa lebih baik, pembelajaran matematika dengan menggunakan GI-S, TPS-S, atau K-S pada materi pokok himpunan, (2) manakah siswa yang mempunyai prestasi belajar lebih baik, siswa dengan AQ tipe quitter, tipe camper, atau tipe climber dalam pembelajaran matematika materi pokok himpunan, (3) pada masing-masing model pembelajaran, manakah siswa yang mempunyai prestasi belajar lebih baik, siswa dengan AQ tipe quitter, tipe camper, atau tipe climber dalam pembelajaran matematika materi pokok himpunan, (4) pada masing-masing tipe $\mathrm{AQ}$, manakah model pembelajaran yang memberikan prestasi belajar siswa lebih baik, pembelajaran matematika dengan menggunakan GI-S, TPS-S, atau K-S pada materi pokok himpunan.

\section{METODE PENELITIAN}

Penelitian ini dilaksanakan di SMP Negeri di Kabupaten Bantul. Jenis penelitian yang digunakan adalah penelitian eksperimental semu (Quasi experimental research). Dalam penelitian ini terdapat dua variabel bebas yaitu model pembelajaran dan AQ, dan satu variabel terikat yaitu prestasi belajar matematika. Rancangan yang digunakan dalam penelitian ini adalah rancangan faktorial 3 x 3 pada ANAVA dua jalan sel tak sama.

Populasi penelitian ini seluruh siswa kelas VII SMPN di Kabupaten Bantul tahun pelajaran 2014/2015 dari 47 SMP Negeri. Teknik pengambilan sampel yang digunakan adalah teknik stratified cluster random sampling. Adapun sampel penelitiannya adalah siswa SMP Negeri 1 Pleret (kategori tinggi), SMP Negeri 2 Sewon (kategori sedang), dan SMP Negeri 4 Banguntapan (kategori rendah).

Teknik pengumpulan data menggunakan metode dokumentasi, metode tes, dan metode angket. Sebelum instrumen tes prestasi belajar dan angket AQ siswa dipergunakan, instrumen perlu diuji cobakan. Tes prestasi belajar diuji validitas, uji tingkat kesukaran, uji daya beda soal, dan uji reliabilitas. Sedangkan, angket AQ siswa diuji validitas isi, uji konsistensi internal, dan uji reliabilitas.

Sebelum dilakukan penelitian, dilakukan uji keseimbangan terlebih dahulu dengan menggunakan ANAVA satu jalan sel tak sama untuk mengetahui sampel penelitian berasal dari populasi yang memiliki kemampuan awal yang sama. Sebelum dilakukan uji ANAVA, terlebih dahulu dilakukan uji prasyarat analisis variansi yang terdiri dari Uji Normalitas menggunakan metode Lilliefors dan Uji Homogenitas 
menggunakan uji Bartlett. Pengujian hipotesis penelitian menggunakan ANAVA dua jalan dengan sel tak sama dan untuk uji lanjut pasca ANAVA dilakukan dengan metode Scheffe'.

\section{HASIL PENELITIAN DAN PEMBAHASAN}

Hasil uji prasyarat menyatakan bahwa sampel berasal dari populasi yang berdistribusi normal dan populasi mempunyai variansi yang homogen. Berdasarkan hasil uji keseimbangan diperoleh $F_{\text {obs }}=0,0139$ dan $F_{0,05 ; 2 ; 250}=3,0319$ dengan $\mathrm{DK}=\{F \mid F>3,0319\}$ maka $F_{\text {obs }} \notin \mathrm{DK}$ dan keputusan ujinya adalah $H_{0}$ tidak ditolak. Hal ini berarti bahwa populasi mempunyai kemampuan awal yang sama. Rangkuman hasil perhitungan ANAVA dua jalan dengan sel tak sama dengan taraf signifikansi $\alpha=0,05$ disajikan dalam Tabel 1 .

Tabel 1. Rangkuman Hasil ANAVA Dua Jalan Sel Tak Sama

\begin{tabular}{lcccccc}
\hline \multicolumn{1}{c}{ Sumber } & JK & dk & RK & $F_{\text {obs }}$ & $F_{\text {tabel }}$ & $\begin{array}{c}\text { Keputusan } \\
\text { Uji }\end{array}$ \\
\hline Model (A) & 55,7818 & 2 & 27,8909 & 21,1661 & 3,0328 & $H_{0 A}$ ditolak \\
AQ (B) & 102,6563 & 2 & 51,3282 & 38,9524 & 3,0328 & $H_{0 B}$ ditolak \\
Interaksi (AB) & 12,9904 & 4 & 3,2476 & 2,4646 & 2,4086 & $H_{0 A B}$ ditolak \\
Galat & 321,5223 & 224 & 1,3177 & & & \\
Total & 492,9508 & 252 & 21,1661 & & & \\
\hline
\end{tabular}

Berdasarkan Tabel 1 diketahui $H_{0 A}, H_{0 B}$, dan $H_{0 A B}$ ditolak. Hal ini menunjukkan bahwa terdapat perbedaan pengaruh model pembelajaran terhadap prestasi belajar matematika, pengaruh tipe AQ siswa terhadap prestasi belajar matematika, dan terdapat interaksi antara model pembelajaran dan tipe AQ siswa terhadap prestasi belajar matematika. Oleh sebab itu, perlu dilakukan uji komparasi ganda dengan menentukan rerata masing-masing sel dan rerata marginal terlebih dahulu, hasilnya disajikan dalam Tabel 2.

Tabel 2. Rerata Sel dan Rerata Marginal Prestasi Belajar Matematika

\begin{tabular}{lcccc}
\hline \multicolumn{1}{c}{ Model } & \multicolumn{3}{c}{ Adversity Quotient } & \multirow{2}{*}{ Rerata Marginal } \\
\hline Pembelajaran & Climber & Camper & Quitter & \\
TPS & 8,2968 & 7,6400 & 7,0000 & 7,6988 \\
Klasikal & 7,9385 & 7,6000 & 6,0800 & 7,2482 \\
Rerata Marginal & 7,4345 & 6,1778 & 5,8897 & 6,5082 \\
\hline
\end{tabular}

Hasil uji ANAVA dua jalan sel tak sama menunjukkan $H_{0 A}$ ditolak, sehingga perlu dilakukan uji komparasi ganda antar baris dengan metode Scheffe'. Rangkuman hasil uji rerata antar baris disajikan pada Tabel 3. 
Tabel 3. Ragkuman Hasil Uji Komparasi Rerata Antar Baris

\begin{tabular}{cccc}
\hline$H_{0}$ & $F_{\text {hit }}$ & 2. $F_{0,05 ; 2,244}$ & Keputusan Uji \\
\hline$\mu_{1 \cdot}=\mu_{2 \cdot}$ & 6,4715 & 6,0656 & $H_{0}$ ditolak \\
$\mu_{2 \cdot}=\mu_{3 \cdot}$ & 17,4494 & 6,0656 & $H_{0}$ ditolak \\
$\mu_{1 \cdot}=\mu_{3 \cdot}$ & 45,7184 & 6,0656 & $H_{0}$ ditolak \\
\hline
\end{tabular}

Berdasarkan Tabel 3 diketahui terdapat perbedaan prestasi belajar matematika siswa yang diberi pembelajaran menggunakan masing-masing model pembelajaran. Dengan memperhatikan rerata marginalnya, dapat disimpulkan bahwa prestasi belajar matematika siswa yang diberi pembelajaran menggunakan GI-S lebih baik jika dibandingkan dengan siswa yang diberi pembelajaran TPS-S dan K-S. Temuan penelitian lain adalah terdapat perbedaan prestasi belajar matematika siswa yang diberi pembelajaran menggunakan TPS-S dan K-S. Dengan memperhatikan rerata marginalnya, dapat disimpulkan bahwa prestasi belajar matematika siswa yang diberi pembelajaran menggunakan TPS-S lebih baik dibandingkan siswa yang diberi pembelajaran menggunakan K-S.

Hal ini disebabkan dengan GI-S siswa dikelompokkan secara heterogen yang terdiri atas 5- 6 siswa. Siswa terlibat secara maksimal dalam proses pembelajaran. GI-S mampu membuat siswa aktif dalam pembelajaran. Interaksi dalam kelompok ini akan berjalan baik ketika setiap kelompok mempunyai kemampuan yang heterogen, karena dalam pembagian tugas dalam kelompok pada pembelajaran kooperatif ini disesuaikan dengan kemampuan siswa tersebut sehingga mendorong tumbuhnya interdependensi yang bersifat positif diantara anggota kelompok.

Hasil uji ANAVA dua jalan sel tak sama menunjukkan $H_{O B}$ ditolak, sehingga perlu dilakukan uji komparasi ganda antar kolom. Rangkuman hasil uji rerata antar kolom disajikan pada Tabel 4.

Tabel 4. Rangkuman Hasil Uji Komparasi Rerata Antar Kolom

\begin{tabular}{cccc}
\hline$H_{0}$ & $F_{\text {obs }}$ & $2 . F_{0,05 ; 2,244}$ & Keputusan Uji \\
\hline$\mu_{-1}=\mu_{-2}$ & 16,9994 & 6,0656 & $H_{0}$ ditolak \\
$\mu_{-2}=\mu_{-3}$ & 24,9717 & 6,0656 & $H_{0}$ ditolak \\
$\mu_{-1}=\mu_{-3}$ & 79,9975 & 6,0656 & $H_{0}$ ditolak \\
\hline
\end{tabular}

Berdasarkan Tabel 4 diketahui terdapat perbedaan prestasi belajar matematika siswa dengan AQ tipe climber, siswa dengan AQ tipe camper dan tipe quitter. Dengan memperhatikan rerata marginalnya, dapat disimpulkan bahwa prestasi belajar matematika siswa dengan AQ tipe climber lebih baik daripada siswa dengan AQ tipe camper dan tipe quitter. Temuan penelitian lain adalah terdapat perbedaan prestasi belajar matematika siswa dengan AQ tipe camper dengan AQ tipe quitter. Dengan memperhatikan rerata 
marginalnya, dapat disimpulkan bahwa prestasi belajar matematika siswa dengan AQ tipe camper lebih baik daripada siswa dengan AQ tipe quitter.

Selama kegiatan pembelajaran berlangsung, siswa dengan AQ tipe climber sangat aktif dalam proses pembelajaran. Ketika diskusi dan menemukan hal-hal yang tidak dimengerti, siswa tipe climber ini aktif bertanya pada guru maupun pada teman yang lebih memahami materi. Hal tersebut sesuai dengan Stoltz (2004: 85) bahwa siswa yang memiliki AQ tinggi pola responnya lebih konstruktif unggul, serta merespon bahwa kesulitan dianggap sebagai peluang (Stoltz, 2004: 94).

Hasil uji ANAVA dua jalan sel tak sama menunjukkan $H_{0 A B}$ ditolak, sehingga perlu dilakukan uji komparasi rerata antar sel pada baris yang sama. Hasil uji rerata antar sel pada baris yang sama disajikan pada Tabel 5 .

Tabel 5. Rangkuman Hasil Uji Komparasi Rerata Antar Sel pada Baris yang Sama

\begin{tabular}{cccc}
\hline$H_{0}$ & $F_{\text {obs }}$ & $8 . F_{0,05 ; 8,244}$ & Keputusan Uji \\
\hline$\mu_{11}=\mu_{12}$ & 4,9907 & 15,8118 & $H_{0}$ tidak ditolak \\
$\mu_{11}=\mu_{13}$ & 17,2631 & 15,8118 & $H_{0}$ ditolak \\
$\mu_{12}=\mu_{13}$ & 4,1446 & 15,8118 & $H_{0}$ tidak ditolak \\
$\mu_{21}=\mu_{22}$ & 1,2471 & 15,8118 & $H_{0}$ tidak ditolak \\
$\mu_{21}=\mu_{23}$ & 33,4064 & 15,8118 & $H_{0}$ ditolak \\
$\mu_{22}=\mu_{23}$ & 24,6083 & 15,8118 & $H_{0}$ ditolak \\
$\mu_{31}=\mu_{32}$ & 16,7579 & 15,8118 & $H_{0}$ ditolak \\
$\mu_{31}=\mu_{33}$ & 26,2607 & 15,8118 & $H_{0}$ ditolak \\
$\mu_{32}=\mu_{33}$ & 0,8809 & 15,8118 & $H_{0}$ tidak ditolak \\
\hline
\end{tabular}

Berdasarkan Tabel 5 tidak terdapat perbedaan prestasi belajar matematika antara siswa dengan AQ tipe climber dan AQ tipe camper, serta tidak terdapat perbedaan prestasi belajar matematika antara siswa dengan AQ tipe camper dan AQ tipe quitter pada siswa yang diberi pembelajaran dengan GI-S dan TPS-S. Pada proses pembelajaran, siswa belum dapat mengoptimalkan langkah-langkah pembelajaran yang harus diterapkan. Siswa belum bisa menyesuaikan diri sesuai dengan tujuan pembelajaran yang diterapkan pada kurikulum 2013 ini. Siswa terbiasa mendapatkan pembelajaran dengan cara mendengarkan guru dalam menyampaikan materi, melihat contoh-contoh soal yang diberikan oleh guru, serta menggunakan rumus yang diberikan tanpa mengetahui bagaimana cara untuk menyelesaikan suatu permasalahan berdasarkan ide dari pemahaman dan pengetahuan yang dimilikinya.

Temuan lain pada penelitian ini adalah terdapat perbedaan prestasi belajar matematika siswa dengan AQ tipe climber dan AQ tipe quitter pada siswa yang diberi pembelajaran dengan GI-S dan TPS-S. Dengan memperhatikan reratanya, dapat disimpulkan bahwa siswa yang diberi pembelajaran menggunakan GI-S dan TPS-S pada siswa dengan AQ tipe climber mempunyai prestasi belajar matematika yang lebih baik 
daripada siswa dengan AQ tipe quitter. Hal ini sejalan dengan pendapat Sudarman (2012) bahwa siswa dengan AQ tipe quitter beranggapan bahwa matematika rumit, nyelimet, membingungkan, dan bikin pusing. Motivasi mereka sangat kurang, sehingga ketika menemui kesulitan mereka mudah menyerah dan berhenti tanpa dibarengi usaha sedikitpun.

Pada model pembelajaran K-S terdapat perbedaan prestasi belajar matematika antara siswa dengan AQ tipe climber dan AQ tipe camper, serta terdapat perbedaan prestasi belajar matematika antara siswa dengan AQ tipe climber dan AQ tipe quitter. Dengan memperhatikan rerata sel baris, dapat disimpulkan bahwa siswa yang diberi pembelajaran menggunakan model pembelajaran K-S pada siswa dengan AQ tipe climber mempunyai prestasi belajar matematika yang lebih baik daripada siswa dengan AQ tipe camper dan tipe quitter.

Pada model pembelajaran K-S siswa harus menyesuaikan diri dengan program pembelajaran yang telah disusun oleh guru, supaya meteri pembelajaran dapat terselesaikan. Siswa kurang aktif dan kurang mengemukakan ide-ide dalam berinteraksi dengan temannya, karena guru lebih dominan selama proses pembelajaran di kelas. Pada siswa yang mempunyai AQ tipe climber lebih aktif, rajin mendalami materi dan ingin mempunyai prestasi belajar yang lebih baik.

Temuan lain pada penelitian ini adalah tidak terdapat perbedaan prestasi belajar matematika antara siswa dengan AQ tipe camper dan siswa dengan AQ tipe quitter pada siswa yang diberi pembelajaran dengan model pembelajaran K-S. Siswa dengan AQ tipe camper mempunyai prastasi belajar yang lebih baik dari pada siswa dengan AQ tipe quitter. Dalam proses pembelajaran siswa dengan AQ tipe camper kerap mengabaikan kemungkinan-kemungkinan yang bakal didapat dan tidak memaksimalkan usahanya. Sedangkan, siswa dengan AQ tipe quitter cenderung mudah menyerah apabila menemui masalah dalam pembelajaran matematika.

Hasil uji ANAVA dua jalan sel tak sama menunjukkan $H_{0 A B}$ ditolak, sehingga perlu dilakukan uji komparasi rerata antar sel pada kolom yang sama dengan metode Scheffe'. Rangkuman hasil uji rerata antar sel pada kolom yang sama disajikan pada Tabel 6 .

Tabel 6. Rangkuman Hasil Uji Komparasi Rerata Antar Sel pada Kolom yang Sama

\begin{tabular}{cccc}
\hline$H_{0}$ & $F_{\text {hit }}$ & $\mathbf{8} \cdot F_{0,05 ; 8,244}$ & Keputusan Uji \\
\hline$\mu_{11}=\mu_{21}$ & 1,3777 & 15,8118 & $H_{0}$ tidak ditolak \\
$\mu_{11}=\mu_{31}$ & 8,4546 & 15,8118 & $H_{0}$ tidak ditolak \\
$\mu_{21}=\mu_{31}$ & 2,6425 & 15,8118 & $H_{0}$ tidak ditolak \\
$\mu_{12}=\mu_{22}$ & 0,0188 & 15,8118 & $H_{0}$ tidak ditolak \\
$\mu_{12}=\mu_{32}$ & 23,0577 & 15,8118 & $H_{0}$ ditolak \\
$\mu_{22}=\mu_{32}$ & 22,4789 & 15,8118 & $H_{0}$ ditolak \\
\hline
\end{tabular}




\begin{tabular}{cccc}
\hline$\mu_{13}=\mu_{23}$ & 7,8652 & 15,8118 & $H_{0}$ tidak ditolak \\
$\mu_{13}=\mu_{33}$ & 12,2865 & 15,8118 & $H_{0}$ tidak ditolak \\
$\mu_{23}=\mu_{33}$ & 0,3692 & 15,8118 & $H_{0}$ tidak ditolak \\
\hline
\end{tabular}

Tabel 6 menunjukkan hasil bahwa tidak terdapat perbedaan prestasi belajar matematika pada siswa dengan AQ tipe climber, baik siswa yang diberi pembelajaran dengan GI-S, TPS-S, maupun K-S. Ini berarti siswa dengan AQ tipe climber mempunyai prestasi belajar yang sama pada setiap penggunaan model pembelajaran. Sejalan dengan pendapat Sudarman (2012) siswa dengan AQ tipe climber adalah siswa yang mempunyai tujuan atau target. Untuk mencapai tujuan itu, ia mampu mengusahakan dengan ulet dan gigih. Oleh karena itu, model pembelajaran yang dipakai guru tidak berpengaruh pada siswa dengan AQ tipe climber.

Berdasarkan temuan penelitian tidak terdapat perbedaan prestasi belajar matematika pada siswa dengan AQ tipe camper, baik siswa yang diberi pembelajaran dengan GI-S maupun TPS-S. Siswa dengan AQ tipe camper lebih terkondisi dengan pembelajaran kooperatif dengan pendekatan saintifik yang telah diterapkan oleh peneliti. Dalam belajar matematika siswa dengan AQ tipe camper tidak berusaha semaksimal mungkin, mereka berusaha sekedarnya saja.

Temuan lain pada penelitian ini adalah terdapat perbedaan prestasi belajar matematika pada siswa dengan AQ tipe camper, baik siswa yang diberi pembelajaran dengan GI-S dan K-S. Serta, terdapat perbedaan prestasi belajar siswa yang diberi pembelajaran dengan menggunakan TPS-S dan K-S. Ini berarti dengan memperhatikan rerata sel, siswa dengan AQ tipe camper penggunaan GI-S dan TPS-S mempunyai prestasi belajar matematika yang lebih baik daripada penggunaan K-S. Sudarman (2012) menyatakan bahwa siswa dengan AQ tipe camper adalah anak yang tidak mau mengambil resiko yang terlalu besar dan merasa puas dengan kondisi atau keadaan yang telah dicapainya saat ini. Ia pun kerap mengabaikan kemungkinan-kemungkinan yang bakal didapat. Mereka tidak memaksimalkan usahanya walaupun peluang dan kesempatan ada. Dengan K-S, siswa tipe camper kurang termotivasi untuk mendapatkan prestasi yang lebih baik. Karena dengan K-S interaksi antar siswa kurang dan guru lebih dominan dalam menentukan proses pembelajaran

Berdasarkan temuan penelitian tidak terdapat perbedaan prestasi belajar matematika pada siswa dengan AQ tipe quitter, baik siswa yang diberi pembelajaran dengan GI-S, TPS-S, maupun K-S. Ini berarti siswa dengan AQ tipe quitter mempunyai prestasi belajar yang sama pada setiap penggunaan model pembelajaran. Peneliti dimungkinkan tidak dapat mengontrol faktor-faktor lain yang muncul dari proses pembelajaran. Siswa tipe quitter tidak dapat mengoptimalkan proses diskusi. Hal itu dikarenakan pada pembelajaran dengan GI-S memerlukan waktu yang lama dalam 
pembelajaran dan adanya tahap pengalaman belajar yang menyebabkan siswa dengan AQ tipe quitter mudah putus asa dalam memahami setiap permasalahan yang diberikan oleh guru. Dalam proses investigasi maupun mengasosiasi materi pembelajaran, siswa AQ tipe quitter mengandalkan siswa lain yang lebih paham. Pada pembelajaran TPS-S, siswa dengan AQ tipe quitter malas untuk berfikir (think) secara sendiri-sendiri. Siswa tipe quitter memilih pasif pada tahapan pair dan share.

\section{SIMPULAN DAN SARAN}

Berdasarkan hasil penelitian dan pembahasan, disimpulkan seperti berikut. (1) Pembelajaran matematika pada materi pokok himpunan dengan GI-S memberikan prestasi belajar lebih baik dibanding dengan TPS-S dan K-S, sedangkan pembelajaran dengan TPS-S memberikan prestasi belajar lebih baik dibanding dengan K-S. (2) Siswa dengan AQ tipe climber mempunyai prestasi belajar lebih baik dibanding siswa dengan AQ tipe camper dan tipe quitter, sedangkan siswa dengan AQ tipe camper mempunyai prestasi belajar lebih baik dibanding siswa dengan AQ tipe quitter dalam pembelajaran matematika materi pokok himpunan. (3) Pada GI-S dan TPS-S, siswa dengan AQ tipe climber dan tipe camper mempunyai prestasi belajar yang sama, sedangkan siswa dengan AQ tipe climber dan tipe camper mempunyai prestasi belajar matematika lebih baik daripada siswa dengan AQ tipe quitter dalam pembelajaran matematika materi pokok himpunan. Pada K-S, siswa dengan AQ tipe climber mempunyai prestasi belajar lebih baik daripada siswa dengan AQ tipe camper dan tipe quitter, sedangkan siswa dengan AQ tipe camper dan tipe quitter mempunyai prestasi belajar yang sama dalam pembelajaran matematika materi pokok himpunan. (4) Pada siswa dengan AQ tipe climber dan tipe quitter GI-S, TPS-S, dan K-S memberikan prestasi belajar yang sama dalam pembelajaran matematika materi pokok himpunan. Pada siswa dengan AQ tipe camper GI-S dan TPS-S memberikan prestasi belajar yang sama, sedangkan GI-S dan TPS-S memberikan prestasi belajar lebih baik daripada K-S dalam pembelajaran matematika materi pokok himpunan.

Berdasarkan simpulan yang telah dipaparkan sebelumnya, dapat dikemukakan saran sebagai berikut. (1) Bagi Guru: model pembelajaran matematika yang dapat diterapkan oleh guru khususnya pada materi pokok himpunan adalah dengan menggunakan GI-S atau TPS-S. Prestasi belajar matematika siswa akan meningkat jika guru menerapkan model pembelajaran yang sesuai dengan tipe AQ siswa. Siswa dengan AQ tipe climber dan tipe quitter penerapan model pembelajaran tidak berpengaruh terhadap prestasi belajar matematika. Siswa dengan AQ tipe camper guru disarankan menerapkan GI-S atau TPS-S dalam proses pembelajaran. (2) Bagi Kepala Sekolah: 
Menghimbau guru untuk menerapkan GI-S atau TPS-S dalam proses pembelajaran khususnya materi pokok himpunan. Menghimbau guru untuk memperhatikan karakteristik siswa khususnya AQ dalam pembelajaran, karena hasil penelitian menunjukkan tipe AQ siswa berpengaruh terhadap prestasi belajar. (3) Bagi Peneliti Lain: Diharapkan dapat mengembangkan penelitian ini pada materi pokok lain agar penelitian ini dapat dimanfaatkan secara luas. Peneliti lain ketika melakukan penelitian dengan GIS, TPS-S, dan AQ diharapkan memperhatikan variabel atribut lain yang kemungkinan dapat mempengaruhi hasil penelitian.

\section{DAFTAR PUSTAKA}

Badan Standar Nasional Pendidikan (BSNP). 2014. Laporan Hasil Ujian Nasional Tahun Pelajaran 2013/2014.

Dimyati \& Mudjiono. 2006. Belajar dan Pembelajaran. Jakarta: Rineka Cipta.

Furner, J. M. and Kumar, D. D. 2007. The Mathematics and Science Integration Argument: A Stand for Teacher Education, Eurasia Journal of Mathematics, Science \& Technology Education, 3(3): 185 - 189.

Ignacio, N. G., Blanco Nieto, L. J. \& Barona, E. G. 2006. The Affective Domain In Mathematics Learning. International Electronic Journal of Mathematics Education. 1 (1): $16-32$.

Fitriana, L. 2010. Pengaruh Model Pembelajaran Cooperative Tipe Group Investigation (GI) dan STAD terhadap Prestasi Belajar Matematika ditinjau dari Kemandirian Belajar Siswa. Tesis: Universitas Sebelas Maret Surakarta.

Lie, A. 2008. Mempraktekkan Cooperative Learning di Ruang-ruang Kelas. Jakarta: PT Grasindo Remaja Rosdakarya.

Pandya, S. 2011. Interactive Effect of Co-operative Learning Model and Learning Goals of Students on Academic Achievement of Students in Mathematics, Mevlana International Journal of Education (MIJE), 1(2): 27 - 34.

Puteh M., Ahmad C. C. N., Noh M. N., Adnan, M., and Ibrahim M. H. 2014. The Classroom Physical Environment and Its Relation to Teaching and Learning Comfort Level, International Journal of Social Science and Humanity, 5(3): 237 -240 .

Handayani, S. S. 2010. Eksperimentasi Pembelajaran Matematika dengan Menggunakan Model Struktural "Think-Pair-Share" pada Materi Pokok Bentuk Akar dan Pangkat ditinjau dari Gaya Belajar Matematika Siswa.Tesis : Universitas Sebelas Maret Surakarta.

Nureini, S. 2011. Eksperimentasi Pembelajaran Matematika dengan Model Pembelajaran Think-Talk-Write (TTW) dan Numbered Heads Together (NHT) ditinjau dari Adversity Quotient Siswa Kelas VIII SMP di Surakarta. Tesis: Universitas Sebelas Maret Surakarta. 
Phoolka, S. \& Kaur, N. 2012. Adversity Quotient: A New Paradigm to Explore, International Journal of Contemporary Busines Studies, 3(4): 2156 - 7506.

Slavin, R. E. 2005. Cooperative Learning (Teori, Riset, dan Praktik). Bandung: Nusa Media.

Stoltz. 2004. Adversity Quotients Mengubah Hambatan Menjadi Peluang. Jakarta: Grasindo.

Sudarman. 2012. Adversity Quotients : Kajian Kemungkinan Pengintegrasiannya dalam Pembelajaran Matematika.Jurnal Pendidikan. Vol. 1(1). pp. 55 - 62.

Zakaria, E., Chin, L., and Daud, M. Y. 2010. The Effects of Cooperative Learning on Students' Mathematics Achievement and Attitude towards Mathematics. Journal of Social Sciences. Vol. 6(2). pp. 272-275. 